\title{
Effect of Short-Term Inhalation of The Herbicide 2,4D on Cardiac Remodeling: Morphological Aspects
}

Ana Lucia Ribeiro Negrão, ${ }^{\circledR}$ Bianca de Oliveira, ${ }^{\circledR}$ Mariana de Godoy Gonçalves, ${ }^{(\bullet}$ Thaoan Bruno Mariano, Tais Fernanda da Silva Oliveira, ${ }^{\circledR}$ Ana Karênina Dias Almeida Sabela, ${ }^{\circledR}$ Renata Calciolari Rossi e Silva, ${ }^{\circledR}$ Raíssa de Oliveira Mantovani, ${ }^{\circledR}$ Gisele Alborghetti Nai, ${ }^{\circledR}$ Francis Lopes Pacagnelli ${ }^{\circledR}$

Universidade do Oeste Paulista (UNOESTE), Presidente Prudente, SP - Brazil

\section{Abstract}

Background: Brazil is the worldwide leader in the long-term use of pesticides and herbicides. This compromises the health of handlers by causing harmful neurological, respiratory, and cardiovascular changes. The herbicide 2.4D has been shown to cause cardiac overload with subsequent pathological remodeling.

Objective: To analyze the cardiac morphological repercussions on the left ventricle (LV) of mice submitted to nebulization by the herbicide $2.4 \mathrm{D}$.

Methods: Fifteen mice were divided into three groups: control group (CG; $\mathrm{n}=5$ ) exposed to nebulization with sodium chloride solution; low concentration group (LCG; $n=5$ ) exposed to nebulization of the herbicide 2.4D with $3.71 \times 10-3$ grams; and high concentration group (HCG; $n=5$ ) exposed to nebulization of the herbicide 2.4D with $9.28 \times 10-3$ grams for 15 minutes. The fractal dimension analysis was performed through the box-counting method. Later, the ImageJ program was used to calculate the fractal dimension of each group. To evaluate cardiac remodeling, histological slides were prepared and stained with Hematoxylin-Eosin (HE). Fifty areas of cardiomyocytes were analyzed per animal. The comparisons between groups were performed by ANOVA OneWay with Tukey's posttest $(\mathrm{p}<0.05)$.

Results: There was no change in fractal dimension values between the CG $=1.37 \pm 0.02$, $L C G=1.33 \pm 0.04$ and the $\mathrm{HCG}=1.33 \pm 0.07$ groups. However, cardiac hypertrophy occurred in the $\mathrm{HCG}=303.9 \pm 38.80 \mu \mathrm{m}^{2}$ when compared to the CG group $=236.9 \pm 61.71 \mu \mathrm{m}^{2}(\mathrm{p}=0.034)$.

Conclusion: The herbicide $2.4 \mathrm{D}$ used for 72 hours did not promote cardiotoxicity when evaluated by fractal dimension. However, cardiomyocyte hypertrophy was observed in the LV. (Int J Cardiovasc Sci. 2019;32(3)247-252)

Keywords: Mice; Pesticides/adverse effects; Herbicides / adverse effects; Agrochemicals; Neurologic Manifestations; Respiratory Tract Diseases; Hypertrophy,Left Ventricular.

\section{Introduction}

Herbicides are pesticides used in agriculture, plants and crops (green vegetables, fruits and vegetables) used to protect, repel and fight the proliferation of living organisms (pests, fungi, insects, weeds, birds, mollusks, microbes and arachnids) that are harmful to the agricultural production. ${ }^{1-5}$ They are classified according to their toxicity, which may range from low to extreme, constituting a great risk to the health and the environment. ${ }^{1,3-5}$

According to the Brazilian Department of the Environment, Brazil is the worldwide leader in the consumption of agrochemicals, due to the vast culture and source of labor in agriculture. ${ }^{6}$ Since 2003, the agrochemical market has increased its use 
by $93 \%$, with Brazil being the leader in consumption worldwide, a position previously occupied by the United States. ${ }^{7}$ The Ministry of Health considers that there are more than 100,000 chemical substances capable of causing chemical, physical, morphological and pathophysiological damage to the health of populations. ${ }^{8-12}$ Among those who suffer the most from the exaggerated use of agrochemicals are rural workers, when these substances are utilized incorrectly.6,9

In 1990, the World Health Organization (WHO) estimated that approximately 3,000,000 cases of pesticide poisoning occurred per year in the world, with 220,000 deaths per year. ${ }^{13}$ Only in 2009, more than 1 billion liters of agrochemicals were utilized in Brazil; it is the same as if each one of the Brazilian individuals consumed an average of five liters of poison per year. ${ }^{14}$ In Brazil, pesticide poisoning is a public health problem and a matter of compulsory notification. ${ }^{15}$

The toxicity can be fast or slow and it can take from months to years for symptoms to appear in the worker exposed to the pesticide. Among the harmful effects are allergic reactions, skin and eye irritation, neurological, respiratory, hematopoietic, hepatic, nephrological, gastrointestinal, pancreatic, and cardiovascular alterations, as well as several toxic reactions. ${ }^{9-12}$ The effects of several types of pesticides have already been well established, resulting in cardiotoxicity with mitochondrial alterations, oxidative stress, hypotrophy, and molecular alterations of gene expression related to cardiac calcium. ${ }^{16-19}$

One of the herbicides frequently used to fight weeds in sugarcane plantations is $2,4 \mathrm{D}$ (2,4-dichlorophenoxyacetic acid), ${ }^{6}$ which has harmful effects when ingested, absorbed by the skin and/or inhaled. This herbicide can cause peripheral neuritis and transient diabetes during exposure to it, as well as loss of appetite, skin irritation, nausea, gastrointestinal tract irritation, vomiting, chest and abdominal pain, exhaustion, weakness, muscle twitching, mental confusion, seizures and even coma. If $2,4 \mathrm{D}$ is used at high concentrations, it may cause degenerative liver and kidney lesions. ${ }^{20}$ However, to the best of our knowledge, there have been no studies evaluating the cardiotoxic effects of 2,4 D using a nebulizing spray containing a sodium chloride $(\mathrm{NaCl})$ solution during a $72 \mathrm{~h}$-period. The aim of this study was to analyze the cardiac morphological effects on the left ventricle (LV) of mice submitted to daily nebulizing sprays containing the $2,4 \mathrm{D}$ herbicide for 15 minutes. It is hypothesized that exposure to high concentrations of 2,4D herbicide will lead to cardiac remodeling.

\section{Methods}

\section{Ethical aspects}

This was an experimental cross-sectional study submitted to the Animal Ethics Committee of Universidade do Oeste Paulista and evaluated by the Animal Use Ethics Commission (CEUA, from the Portuguese Comissão De Ética do Uso De Animais), and approved under protocol n. 3331 to be performed according to the Guide for the Care and Use of Laboratory Animals of the Institutes of Health (USA).

\section{Sample characterization}

For the experiment, 15 male Swiss mice (30-40 g) were provided by the Animal Center of Universidade do Oeste Paulista, where they were housed in collective

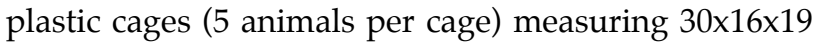
centimeters, under a mean temperature of $22 \pm 2^{\circ} \mathrm{C}$, with 12-hour cycles of light and dark, i.e., light from 7AM to 7PM and dark from 7PM to 7AM. To perform the experiment, the 15 animals were randomly divided into three groups, using the simple randomization method (random sequence performed through Excel):

- CG: control group $(\mathrm{n}=5)$ exposed to nebulization with sodium chloride solution $(\mathrm{NaCl})$ for 15 minutes/ day, for 3 consecutive days.

- LCG: low concentration group $(n=5)$ exposed to nebulization of 2,4D herbicide with $3.71 \times 10-3$ grams of active ingredient per hectare (g.i.a./ ha) for 15 minutes / day, for 3 consecutive days.

- HCG: high concentration group $(n=5)$ exposed to nebulization of 2,4D herbicide with $9.28 \times 10-3$ grams of active ingredient per hectare (g.i.a/ha) for 15 minutes / day, for 3 consecutive days.

\subsection{Herbicide Exposure Protocol}

The experimental protocol used two boxes of 2.4D $(32 \times 24 \times 32 \mathrm{~cm})$, each attached to a Pulmosonic Star ${ }^{\circledR 9}$ ultrasonic nebulizer, and the following concentrations were administered after being diluted in $10 \mathrm{~mL}$ of $0.9 \%$ sodium chloride:

\footnotetext{
- CG: $10 \mathrm{~mL}$ of $0.9 \%$ sodium chloride;

- LCG: Solution consisting of 3.71 x 10-3 grams of active
} 
ingredient per hectare (g.i.a/ ha) of 2,4D, diluted in $10 \mathrm{~mL}$ of $0.9 \%$ sodium chloride. The time of exposure consisted of 15 minutes / day on 3 consecutive days.

- HCG: Solution consisting of $9.28 \times 10-3$ grams of active ingredient per hectare (g.i.a/ha) of 2,4-D diluted in $10 \mathrm{~mL}$ of $0.9 \%$ sodium chloride. The time of exposure was 15 minutes/day for 3 consecutive days.

On the first day of exposure, all 15 animals were submitted to the nebulization with the recommended concentration for each group. After the 3 consecutive days of nebulization, they were anesthetized with Thiopental Sodium, at a dose of $100 \mathrm{mg} / \mathrm{kg}$ of weight, administered in the peritoneal cavity. Soon after being euthanized, the animals had their hearts fixed in 10\% buffered formalin for 72 hours.

\section{Histological and histomorphometric analyses}

After being fixed in formalin, the tissue was embedded in paraffin blocks to obtain 4-micrometer thick coronal histological sections. The histological sections were stained on a slide with the Hematoxylin-Eosin (HE) solution to measure cardiomyocyte cross-sectional areas using a LEICA microscope (model DM750, Germany), which sends digital images to the computer using the LeicaApplication Suite LAS 4.2.0 image analysis system (Media Cybernetics, Silver Spring, Maryland, USA). ${ }^{21,22}$

The images were obtained using a binocular optical microscope. All images were captured by video camera at 400x magnification (40x objective). Four LV sections were obtained from each animal and different field captures were analyzed, which were chosen according to the place where more cells could be visualized in a cross-sectional view. ${ }^{22,23}$ Fifty cells were measured per analyzed ventricle. The selected cardiomyocytes were transversely sectioned and exhibited a round shape, with a nucleus visible in the center of the cell and were located in the subendocardial layer of the LV muscle wall. ${ }^{22,23}$ The mean sectional areas obtained for each group were used as indicators of cell size. ${ }^{23} \mathrm{We}$ also performed the fractal dimension analysis through the box-counting method, in which 3 images were captured per each analyzed slide; after that, the ImageJ program was used to calculate the fractal dimension of each group (Figure 1). This careful technique aims to standardize the set of cardiomyocytes from the different groups to the maximum. The mean sectional areas obtained for each group were used as indicators of cell size. ${ }^{23}$

\section{Statistical analysis}

The software GraphPadPrism was used for the statistical analysis. The Shapiro-Wilk test was performed to analyze data normality. The data showed normal distribution and were presented as mean \pm standard deviation. One-Way ANOVA followed by Tukey test $(\mathrm{p}<0.05)$ were performed for comparison between the groups.

\section{Results}

There was no alteration in the fractal dimension parameter between the CG $=1.37 \pm 0.02, \mathrm{LCG}=1.33$ \pm 0.04 and HCG $=1.33 \pm 0.07$ groups $(p>0.05)$. The animals submitted to a high dose of the herbicide had cardiomyocyte hypertrophy $\left(\mathrm{HCG}=303.9 \pm 38.80 \mu \mathrm{m}^{2}\right)$ when compared to the control group (CG $=236.9 \pm$ $61.71 \mu \mathrm{m}^{2} ; \mathrm{p}=0.034$ ). (Figure 2).

\section{Discussion}

To the best of our knowledge, this is the first study showing that the inhalation of 2,4D herbicide at high concentrations for a short time in mice causes cardiac remodeling.

The 2,4D herbicide, when inhaled, is absorbed and distributed by the lungs, kidney and circulatory system. Enzymes promote the metabolism of the herbicide in these organs and tissues, which results in the formation of free radicals, which can be often more toxic than the herbicide itself. ${ }^{24}$ Oxidative stress is caused by the release of free radicals, and it is an important mechanism that causes cell mutations. ${ }^{24-26}$ There is strong evidence that oxidative stress plays a prominent pathophysiological role in cardiac remodeling. ${ }^{27-28}$ The remodeling process is associated with changes in different mechanisms related to cardiac dysfunction, such as alterations in LV geometry, wall thickness, cavity diameter and normal configuration. ${ }^{24-26}$

The animals of this study that inhaled 2,4D herbicide at a high concentration showed left ventricular hypertrophy, which suggests the development of cardiotoxicity and confirms the action of the $2,4 \mathrm{D}$ in the development of cardiac remodeling. Other studies using the same experimental model in rats indicate that the ingestion of a dose equivalent to $10 \%$ of the lethal dose (LD50) of oral pyrethroid insecticides causes changes in ventricular depolarization and repolarization, suggesting cardiotoxicity. ${ }^{27,28}$ 


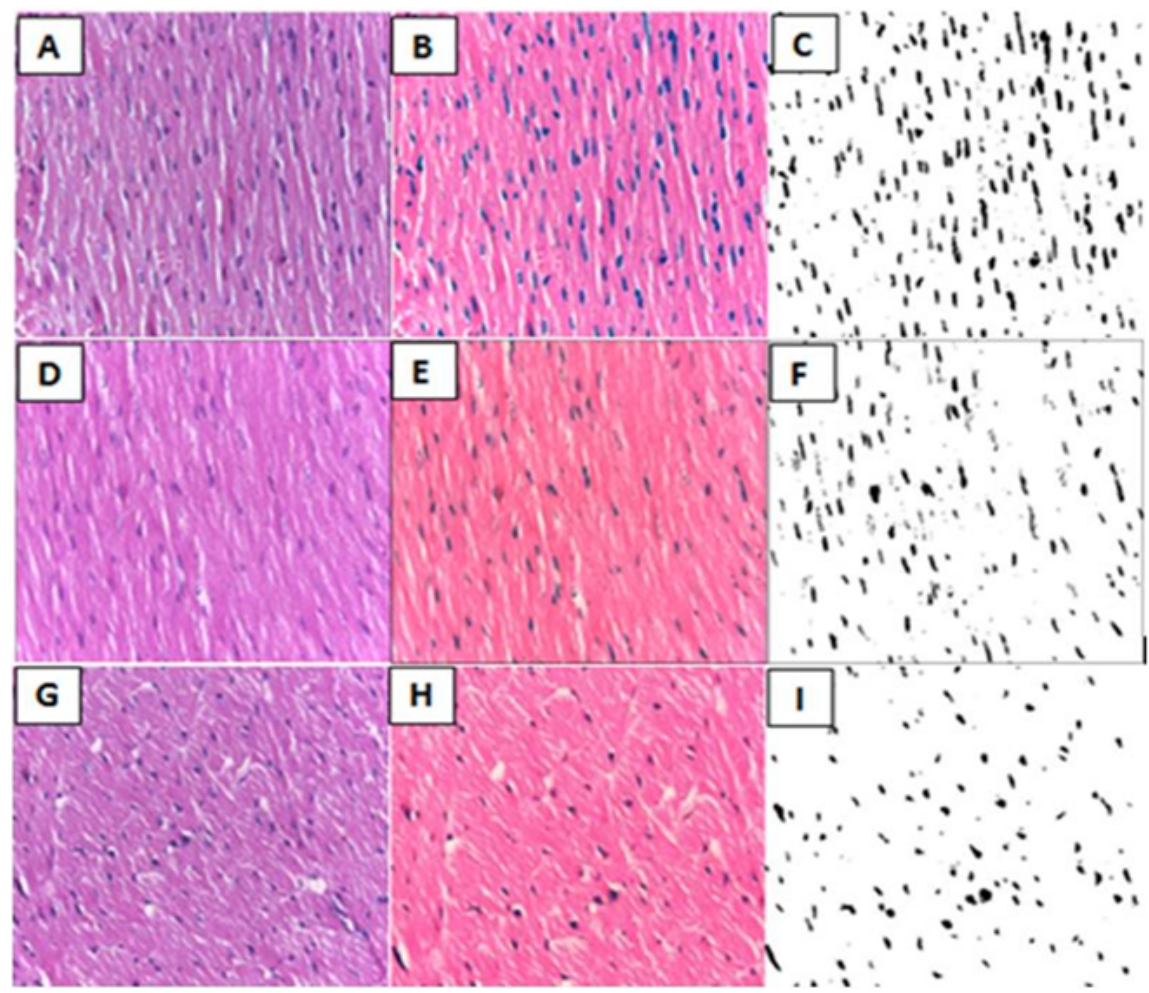

Figure 1 - Letter: A, D, G) Histological section of the left ventricle stained with Hematoxylin and Eosin (HE), 40x increase in the Control Group (CG, $n=5$ ), Low Concentration Group (LCG, $n=5$ ) and High Concentration Group (HCG $n=5$ ). B, E, H) Binarization process in the Control Group (CG, $n=5$ ), Low Concentration Group (LCG, $n=5$ ) and High Concentration Group (HCG $n=5)$. C, F, I) HE image after the binarization process in the Control Group (CG, $n=5)$, Low Concentration Group (LCG, $n=5)$ and High Concentration Group (HCG $\mathbf{n}=5$ ). The cell nuclei can be observed in black and the rest of the cell (cytoplasm, plasma membrane and other elements), in white.

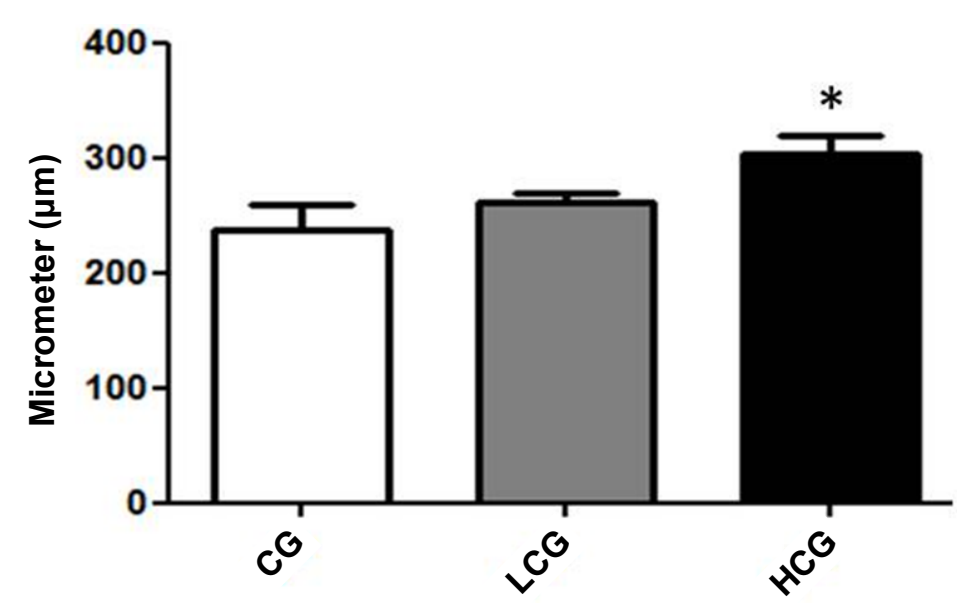

Figure 2 - Analysis of cardiomyocyte hypertrophy.

CG: control group, LCG: low concentration group, HCG: high concentration group. $\left({ }^{*} p<0.05\right.$ when comparing HCG versus CG). 
In another study, Razavi ${ }^{26}$ shows that exposure to Diazinon (DZN) through a catheter once a day, during a 4-week period, also resulted in cardiac lesions in rats and cardiac hypertrophy in the DZN group, showing that this exposure chronically induces infiltration of inflammatory cells and necrosis in cardiac tissue, where they play an important role in cardiotoxicity.

The analysis of the fractal dimension did not demonstrate a significant increase in the animals exposed to the 2,4D herbicide in the HCG $(n=5)$ when compared to the CG animals $(n=5)$, suggesting that there was no cardiotoxicity when it evaluated by the fractal dimension method. This method reveals the irregularities in the histological slides, and the increase in the inflammatory process and the collagen can cause these alterations, as it occurs in cardiac remodeling. ${ }^{29,30}$ Possibly, these changes did not occur in the short term. Further studies involving the inhalation route and chronic exposure might disclose these alterations.

This study becomes extremely relevant from the clinical point-of-view, as it demonstrates the acute potential for short-term cardiac damage when herbicides are inhaled. Considering that the workload of rural workers exceeds this period, it is important to use personal protective equipment (PPE), and this information must be disclosed to farmers, alerting them to the risks of heart disease. ${ }^{30,32}$

As a study limitation, we can cite sample size, with only 5 animals per group.

The results of this study, which is a translational research, show the possible heart damage that can be caused by pesticide exposure in the body of rural workers during their work routine. The pesticides can result in damage to the cardiac function and thus cause signs and symptoms of intolerance to exertion, such as fatigue and dyspnea. Control strategies to prevent the inhalation of these substances by rural workers are necessary to prevent progression to pathological cardiac remodeling. ${ }^{8}$ Moreover, further analyses may also be used to characterize other pathological cardiac alterations, such as molecular analyses of the heart and evaluations of systolic and diastolic functions by echocardiography. The mechanisms involved in cardiac hypertrophy should also be elucidated. ${ }^{33}$

\section{Conclusion}

The 2,4D herbicide at acutely inhaled concentrations promoted cardiomyocyte hypertrophy in mice, showing its potential in causing pathological cardiac remodeling.

\section{Author contributions}

Conception and design of the research: Pacagnelli FL, Mariano TB, Sabela AKDA, Silva RCR, Nai GA. Acquisition of data: Negrão ALR, Oliveira B, Gonçalves MG, Oliveira TFS. Analysis and interpretation of the data: Negrão ALR, Oliveira B, Gonçalves MG. Statistical analysis: Mantovani RO. Obtaining financing: Pacagnelli FL. Writing of the manuscript: Pacagnelli FL, Negrão ALR, Oliveira B, Gonçalves MG. Critical revision of the manuscript for intellectual content: Silva RCR, Nai GA. Supervision / as the major investigador: Pacagnelli FL.

\section{Potential Conflict of Interest}

No potential conflict of interest relevant to this article was reported.

\section{Sources of Funding}

There were no external funding sources for this study.

\section{Study Association}

This study is not associated with any thesis or dissertation work.

\section{Ethics approval and consent to participate}

This study was approved by the Ethics Committee on Animal Experiments of the University of Western São Paulo (UNOESTE) under the protocol number 3331.

\section{References}

1. Brasil. Ministério da Saúde, Secretaria de Vigilância Sanitária, Departamento Técnico-Normativo, Divisão de Meio Ambiente e Ecologia Humana. Manual de vigilância da saúde de populações expostas a agrotóxicos. Brasilia;1997. P.57-69.

2. Song Y. Insight into the mode of action of 2,4-Dichlorophenoxyaceticacid (2,4-D) as an herbicide. J Integr Plant Biol. 2014;56(2):106-13.

3. Brasil. Presidência da República, Subchefia para Assuntos Jurídicos. Lei No. 7.802 de 11 de julho de 1989. Dispõe sobre a pesquisa, a 
experimentação, a produção, a embalagem e rotulagem, o transporte, o armazenamento, a comercialização, a propaganda comercial, a utilização, a importação, a exportação, o destino final dos resíduos e embalagens, o registro, a classificação, o controle, a inspeção e a fiscalização de agrotóxicos, seus componentes e afins, e dá outras providências. Diário Oficial da União, Brasília (1989 jul. 12).

4. Machi AR, Ferrari L, Mendes A, Arthur V. Effects of gamma radiation (60Co) on herbicide 2,4-D in control of dayflower (Commelina virginica.L). Rev Verde. 2014;9(3):258-62.

5. Faria NMX, Fassa AG, Facchini LA. Pesticides poisoning in Brazil: the official notification system and challenges to conducting epidemiological studies. Ciênc Saude Coletiva. 2007;12(1):25-38.

6. Rigotto RM, Vasconcelos DP, Rocha MM. Pesticide use in Brazil and problems for public health. Cad Saude Publica. 2014;30(7):1360-2.

7. Domingues MR, Bernardi MR, Ono EYS, Ono MA. Pesticides: Risk to Rural Worker Health. Semina: Ciências Biológicas e da Saúde. 2004;25(1):45-54.

8. Mannetje A, Eng A, Walls C, Dryson E, McLean D, Kogevinas M, et al. Serum concentrations of chlorinated dibenzo-p-dioxins, furans and PCBs, among former phenoxy herbicide production workers and firefighters in New Zealand. Int Arch Occup Environ Health. 2016;89(2):307-18.

9. Silver SR, Bertke SJ, Hines CJ, Alavanja MC, Hoppin JA, Lubin JH, et al. Cancer incidence and metolachlor use in the Agricultural Health Study: An update. Int. J. Cancer. 2015;137(11): 2630-43.

10. Evangelou E, Ntritsos G, Chondrogiorgi M, Kavvoura FK, Hernández AF, Ntzani EE, et al. Exposure to pesticides and diabetes: a systematic review and meta-analysis. Environ. Int. 2016 May;91:60-8.

11. Mostafalou S, Abdollahi M. Pesticides and human chronic diseases: Evidences, mechanisms, and perspectives. Toxicol. Appl. Pharmacol. 2013;268(2):157-77.

12. Vasilaki F, Tsitsimpikou C, Tsarouhas K, Germanakis I, Tzardi M, Kavvalakis M, et al. Cardiotoxicity in rabbits after long-term nandrolone decanoate administration. Toxicol Lett. 2016;241:143-151.

13. Malaspina FG, Zinilise ML, Bueno PC. Epidemiologic profile of the pesticides intoxication in Brazil, in the period 1995 to 2010. Cad. Saude Colet. 2011;19(4):425-34.

14. Oliveira NP, Moi GP, Atanaka-Santos M, Silva AMC, Pignati WA. Congenital defects in the cities with high use of pesticides in the state of Mato Grosso, Brazil. Ciênc. Saúde coletiva. 2014;19(10):4123-30.

15. Brasil. Ministério da Saúde. Define as terminologias adotadas em legislação nacional, conforme o disposto no Regulamento Sanitário Internacional 2005 (RSI 2005), a relação de doenças, agravos e eventos em saúde pública de notificação compulsória em todo o território nacional e estabelece fluxo, critérios, responsabilidades e atribuições aos profissionais e serviços de saúde. Portaria n. 104, 25 de janeiro 2011.

16. Abdolghaffari AH, Baghaei A, Solgi R, Gooshe M, Baeeri M, Nigjeh N, et al. Molecular and biochemical evidences on the protective effects of Triiodothyronine against phosphine-induced cardiac and mitochondrial toxicity. Life Sci. 2015 Oct 15;139:30-9.

17. AmaraI IB, Soudani N, Hakim A, Troudi A, Zeghal KM, Boudawara T, et al. Protective effects of vitamin E and selenium against dimethoateinduced cardiotoxicity in vivo: biochemical and histological studies. Environ Toxicol. 2013;28(11):630-43.

18. Solgi R, Baghaei A, Golaghaei A, Hasani S, Baeeri M, Navaei M, et al. Electrophysiological and molecular mechanisms of protection by iron sucrose against phosphine-induced cardiotoxicity: a time course study. Toxicol Mech Methods. 2015;25(4):249-57.

19. DhivyaVadhana MS, Siva Arumugam S, Carloni M, Nasuti C, Gabbianelli R. Early life permethrin treatment leads to long-term cardiotoxicity. Chemosphere. 2013;93(6):1029-34.

20. Myers JP, Antoniou MN, Blumberg B, Carroll L, Colborn T, Everett LG, et al. Concerns over use of glyphosate-based herbicides and risk associated with exposures: a consensus statement. Environ Health. 2016 Feb 17;15:19.

21. Oliveira Júnior SA, Padovani CR, Rodrigues SA, Silva NR, Martinez PF, Campos DHS, et al. Extensive impact of saturated fatty acids on metabolic and cardiovascular profile in rats with diet-induced obesity: a canonical analysis. Cardiovasc Diabetol. 2013 Apr 15;12:65.

22. Matsubara LS, Matsubara BB, Okoshi MP, Cicogna AC, JanickiJS. Alterations in myocardial collagen content affect rat papillary muscle function. Am J Physiol Heart Circ Physiol. 2000;279(4):H1534-9.

23. Huet E, Gabison E, Vallee B, Mougenot N, Linguet G, Riou B, et al. Deletion of extracellular matrix metalloproteinase inducer/CD147 induces altered cardiac extracellular matrix remodeling in aging mice. J Physiol Pharmacol. 2015;66(3):355-66.

24. Friedrich K. Avaliação dos efeitos tóxicos sobre o sistema reprodutivo, hormonal e câncer para seres humanos após o uso do herbicida 2,4D. [tese]. Rio de Janeiro: FIOCRUZ, Instituto Nacional de Controle de Qualidade em Saúde; 2014.

25. Azevedo PS, Polegato BF, Minicucci MF, Paiva SA, Zornoff LA. Cardiac Remodeling: Concepts, Clinical Impact, Pathophysiological Mechanisms and Pharmacologic Treatment. Arq Bras Cardiol. 2016;106(1):e62-9.

26. Razavi BM, Hosseinzadeh H, Movassaghi AR, Imenshahidi M, Abnous K. Protective effect of crocin on diazinon induced cardiotoxicity in rats in subchronic exposure. Chem Biol Interact. 2013;203(3):547-55.

27. Maciel RA. Study of the effects of deltamethrin in the stimulation and cardiac conduction and in the response to oxidative stress in wistar rats. [tese]. Campinas: UNICAMP, Faculdade de Engenharia de Alimentos; 2011.

28. Münzel T, Gori T, Keaney JF Jr, Maack C, Daiber A. Pathophysiological role of oxidative stress in systolic and diastolic heart failure and its therapeutic implications. Eur. Heart J. 2015;36(38):2555-64.

29. Moreira RD, Moriel AR, Murta Junior LO, Neves LA, Godoy MF. Fractal dimension in quantifying the degree of myocardial cellular rejection after cardiac transplantation. Rev Bras Circ Cardiovasc. 2011;26(2):155-63.

30. Tambasco M, Costello BM, Kouznetsov A, Yau A, Magliocco AM. Quantifying the architectural complexity of microscopic images of histology specimens. Micron. 2009;40(4):486-94.

31. Brasil. Presidência da República, Subchefia para Assuntos Jurídicos. Lei n. 5.889 de 8 de Junho de 1973. Estatui Normas Reguladoras do Trabalho Rural e Dá Outras Providências. Diário Oficial da União, Brasília(1973 jun 11); Sec.1:5585.

32. Judai MA, Antunes PA. Ototoxicidade em trabalhadores por exposição a agrotóxicos. IX Fórum Ambiental da Alta Paulista. 2013;9(11):177-85.

33. Pacagnelli FL, Sabela AKDA, Mariano TB, Ozaki GAT, Castoldi RC, Carmo EM, et al. Fractal Dimension in Quantifying ExperimentalPulmonary- Hypertension-Induced Cardiac Dysfunction in Rats. Arq Bras Cardiol. 2016;107(1):33-9. 